\title{
OUDHEIDKUNDIGE OPMERKINGEN.
}

\author{
DOOR \\ G. P. ROUFFAER. \\ (Met een tekst-illustratie.)
}

In onderstaande opmerkingen wordt een poging gedaan om op het gebied der Indische Oudheden eenige namen en feiten te verhelderen, die tot nog toe weinig meer dan klanken of op zich zelf staande gegevens waren gebleven.

\section{Bangka, het "Schip»-eiland.}

Aan verklaring van oude eiland-namen, zoo gewichtig voor onzen Indischen Archipel, is nog buitengewoon veel te doen. Dat Yawa, Djawa, Java, niet "Gierst» of "Gerst», maar Rijst beteekent, is in de laatste tien jaar door meer dan een erkend. ${ }^{1}$ Dat Samoedra, Sumatra, het "Oceaan»-eiland beteekent, en te danken is aan de stad Samoedra aan de Paseirivier op Atjeh's Oostkust, wordt door niemand haast betwijfeld. Dat Broenai, Borneo (misschien zelfs ook Boni) zijn naam

' Zie deze stelling in mijn art. "Tochten (Oudste Ontdekkings-) tot 1497”, in Encyclopaedie van Ned.-Indië, IV (1905), p. 364. Het bezwaar dat Dr. Adriani hiertegen had doen gelden in zijn opstel "De naam der gierst in Midden-Celebes" (Tijdschr. Bat. Gen. LI, 1909, p. 367-373; vooral p. 372-373), gaf hem later aanleiding tot de volgende persoonlijke mededeeling dd. Posso, 22 Febr. 1910: „Het heeft mij onlangs voor het eerst getroffen, dat het Jav. sĕkoel, Kråmå van sĕga [= korrelig gekookte rijsst], in het Soendaasch het woord is voor gierst. Dit sĕkoel is identisch met Mal. sěkoei, Minangkab. sakoei, sakoeai, sikoeai, sakoeih [verg. De Clercq \& Greshoff, Plantkundig Wdb. voor N.-I., 1909, i. v. Setaria italica Beauv., de „tros-gierst”; vroeger geheeten Panicum miliaceum L.]. Zoo wordt dus in sĕko el bewaarheid, wat ge eenmaal in uw Encyclopaedie-artikel „Oudste Ontdekkingstochten tot 1497" hebt nedergeschreven: „Maar deze "gerst” was Rijst”; immers sěkoel moet wel eene andere, althans meer algemeene beteekenis hebben gehad, dan de huidige in 't Jav., waarschijnlijk die van „voedsel", zoodat zij van het eene voedsel op het andere kon overgaan, als het maar een zoo algemeen hoofdvoedsel was, dat het duidelijk genoeg met „voedsel" was aangeduid."

Men vergelijke hiermee nog het analoog geval met Aneityumsch w a $\mathrm{h}={ }_{\text {}}$ food or seed of all sorts" en de daarbij door Prof. Kern vermoede aequivalenten in Indonesische talen: b ĕra s, enz.; zie Verspr. Geschr. V (1916), p. 254 en 261. Oók Skr. y a va wordt in het verkorte Petersburger Wdb. (V, 1884, p. 131) vermeld als: „Getreide, in ältester Zeit vermuthlich mehlgebende Körnerfrucht überb.; in der Folge Gerste" (pers. meded. Dr. Krom). 
dankt aan den woeni-boom (Antidesma Bunius Spreng.), die in 't Maleisch bëroenai heet, kan moeilijk worden ontkend; ' de stad en staat Broenai (misschien het rijk Boni ook) kregen door deze soort boom hun naam, zoo goed als het oude landschap A roe op Noord-Sumatra naar den haroe- of aroe-boom, den welbekenden tjĕmara (Casuarina equisetifolia L.), heette; ${ }^{2}$ de suprematie van Broenai (het Poe-ni, later Boen-lai, der Chin. berichten van $960-1643)^{3}$ gaf daarna den naam aan het heele eiland Borneo, evenals de stad Samoedra aan Sumatra. De naam van het vierde groote Archipel-eiland, Celebes, tart tot heden daarentegen elke gezonde verklaring.

Maar de naam van dat belangrijke eiland van de tweede grootte in Indonesië, Bangka, behoeft weer niet aan redelijken twijfel onderhevig te zijn. Het kan moeilijk iets anders beteekenen als "Schip»-eiland. En wel in dien naderen zin, dat hier aan de naar binnen (d. i. naar het O.) loopende West-kust een groote natuurlijke inbocht voor alle ouderwetsche scheepvaart bestond, tusschen Noord-Sumatra met Malaka eenerzijds, en Java anderzijds, waar men veilig kon liggen om water en brandhout in te nemen, te kalefaten, of een beteren moesson af te wachten; een natuurlijke groote reede tusschen Palembang's modderige Oostkust en de laag-geheuvelde Westkust van het eiland Bangka. Waar die "straat Bangka» dan ook zoowat halverwege van beide kanten was doorgevaren, bij de Mendoek-rivier (alias corrupt S. "Mundo»), is inderdaad de tot nog toe oudste gedateerde inscriptie van onzen geheelen Archipel gevonden (608 Çaka $=686$ A. D.).

Hier dan moet het geweest zijn, dat de oude Indonesische zeeschepen die bangka of wangka heetten, thans beter bekend onder den genasaliseerden vorm wangkang ${ }^{4}$, een pleisterplaats hadden, zoowat halfweg Java en de vele nauwe sělat's of "zeestraten» tusschen Karimoen, Bintan, en het eiland van Singapoera, de Dorado's van zeeroovers nog in de $16^{\mathrm{e}}$ eeuw.

1 Zie De Clereq \& Greshoff, Plantkundig Wdb. voor N.-I., 1909, n² 257.

2 Als boven $\mathrm{n}^{\circ} 698$.

${ }^{3}$ De vraag of het oudere Chin. Po-lo - laat staan Po-li! - niet of wel gelijkwaardig is met Poe-ni, blijve hier ter zijde. Zie het laatst vaN EERDE in Tijdschr. Aardr. Gen. 2, XXX (1913), p. 506-516; en verg. Dr. Schrieke, Het boek van Bonang (1916), p. 16-17.

"Verg. Prof. Kern's „Fidji-taal"; verbeterd herdrukt in Verspr. Geschr. V (1916), i. v. Wangka 1, p. 96. - Een dergelijk, maar kleiner, "Schip". eiland Bangka ligt aan den N. O. uithoek van de Minahasa. 


\section{Parāzvis in 608 Caka (686 A. D.) $=$ Bangka?}

De bedoelde inscriptie van 608 Çaka, door Prof. Kern behandeld in deze Bijdragen, dl. 67 (1913), p. 393-400, als de "Inscriptie van Kota Kapoer», vermeldt driemaal het woord parāwis te midden van een tekst, die geschreven is "in een tot nog toe geheel onbekende taal, die bij alle overeenkomst met het Maleisch op menig punt aanmerkelijk hiervan afwijkt en thans niet meer bestaat" (1. c. p. 400). ${ }^{1}$

De eerste maal staat het in een weinig zeggend verband: jang parsumpahan parāwis, door Prof. Kern vertaald als "de vervloeking (betrekkelijk) Parāwis» (p.397); de tweede maal, helaas, met een waarschijnlijke uitbeitelings-fout: di dalangnja bhāmi parāwis, vertaald als "in de landstreek Parāwis», aangenomen dat er bhūmi had dienen te staan (p. 398); de derde maal het duidelijkst, waar gesproken wordt van: jang wanuān ja parāwis, vertaald met «de bewoners van Parāwis» (1.c.).

De naam van het land "Parāwis", waar deze steen gevonden is geworden, met zijn "vloekbede» (sumpa hi) "bebeiteld» ( $\mathrm{ni}$ $p \bar{a} h a t)$, blijft daarbij echter in het duister.

Toch geloof ik, dat een aannemelijke conjectuur gedaan kan worden. Is de landsnaam "Parāwis» niet een deftigheids-vervorming, een kråmå-vorm, van Oudjav. parahwa, parahoe, prahoe ${ }^{2}$, ons "prauw»? Zoo ja, dan is dat "Parāwis» uit 608 Çaka een kanselarij-woord geweest voor het volkswoord Bang ka, het "Schip»(-eiland); welk laatste scheepswoord, hoewel uit het eigen Maleisch verdwenen, voort is blijven leven in het Soembawaasch, het Bonerateesch, het Binongkoósch, het Tagalog en Bisaja. De mogelijkheid bestaat dan, dat het eiland Bangka in den mond der zeevarende Hindoe-Javanen omtrent $700 \mathrm{~A}$. D. genoemd werd Parahwa; beide "Zeeschip».

Als tegenwoordig nog bestaande $\mathrm{kr}$ å må-vormen op wis, mag hierbij herinnerd worden aan Jav. antawis voor antårå; awis voor anjang, arak, arang, èn zelfs larang; en vooral aan Matawis voor Mataram. Voor Sumatraansche landsnamen op is, denke men aan Laïs; Bĕngkalis is wel=bangka + alis.

1 Thans herdrukt in de Verspr. Geschr. VII (1917), p. 207-214. En zie daar op p. 207 de omschrijving van Dr. Brandes uit 1902: „in een soort Maleisch".

"Voor prahoe, parahoe, parahwa, zie V. d. Tuuk, Kawi-Bal. Wdb. IV (1912), p. 58. Op p. $60 a$ is eene verwijzing parahwa naar praboe vergeten. 
In dit verband moeten nog een drietal opmerkingen worden gemaakt.

De inscriptie van Kota Kapoer eindigt met de vaststelling, dat $\mathrm{zij}$ "is gebeiteld, op het tijdstip waarop het leger van Z. Maj. Widjaja getuchtigd (?) heeft 't Javaansche land dat niet onderdanig was aan Z. Maj. Widjaja» (nipāhat di welānjā jang wala Çrī Widjaja kaliwat manāpikjang bhūmi Djāwa tida bhakti ka Çrī Widjaja), p. 400 en 395; waarin slechts de vertaling van het werkwoord manāpik, dat in regel 4 van het opschrift reeds als tāpik'voorkomt, op gissing berust. Indien de landsnaam $\mathrm{Par} \overline{\mathrm{a}} \mathrm{w}$ is inderdaad als een Kråmå-vorm van Parahwa $=$ Bangka mag beschouwd worden, dan wordt de waarschijnlijkheid haast tot zekerheid, dat met «b h ū mi $\mathrm{Dj} \bar{a} w a$ » niets anders bedoeld is dan het "(ei)land Fava»; en niet het een of ander deel van het (ei)land Sumatra. Dit zou dan ook uitstekend overeenkomen met het feit, dat de twee in ouderdom op deze Bangka-inscriptie volgende gedateerde inschriften van den Indischen Archipel zijn: die van Tjanggal in Zuid-Kĕdoe uit 654 Çaka, verheerlijkende de oprichting van een $1 \mathrm{ing} g$ a door Vorst Sandjaja, evenzeer in Wenggi-karakters als de Kota-Kapoerinscriptie; en die van Dinaja in Pasoeroehan uit 682 Çaka, in Oudjavaansche karakters, verheerlijkende de oprichting van een steenen beeld ter eere van den Ziener Agastya, den mythischen Apostel van Dekkhan, speciaal van de Tamil's. ' En daar nu de steen-zelve, waarop de inscriptie gegrift is, bij het vinden na 12 eeuwen, een lichtelijk verweerde andesiet-pilaar bleek te zijn, welk gesteente op Bangka nergens voorkomt (dus van buiten moet zijn aangebracht), maar daarentegen het meest algemeene gesteente vormt op Java, ${ }^{2}$ zoo is ook dit een versterking van de opvatting, dat met bh ū mi $\mathrm{Dj} \bar{a}$ wa niets anders bedoeld kan zijn als het land van Java; niet Sumatra.

Een ongedachte versterking ligt voorts in de verrassende opmerking van den heer A. LAFEBER, dat van de twee inscripties

1 Zie Dr. Bosch in Tijdschr. Bat. Gen. Gen. LVII (1916), p. 410 vlg. En verg. Dr. G. A. Grierson in The Imperial Gazetteer of India, New edition, II (1908), p. 434: "Tradition refers the commencement of literature in the Tamil country to the Brāhman saint Agastya, the mythical apostle of the Deccan". - Over den Vorst Çrī Widjaja, zie nader p. 147 noot 1.

' Pers. meded. in 1909 van den mijningenieur 1' kl. J. Koosass, die 8 jaar op Bangka verbleef. Zie reeds bij Prof. Kern, l. c. (1913), p. 393; of 1. c. (1917), p. 207, met het aldaar toegevoegd facsimile der in-criptie op p. 209. 
van Gandasoeli (bij Parakan, N. W. Kẹ̣oe), waarvan de eene gedateerd was 769 Çaka, de andere en meer uitvoerige ongedateerd zich nog bevindt op een rotsblok ter plaatse, (resp. $\mathrm{n}^{\text {os }}$ III en CV uit de Oudjavaansche Oorkonden-transcripties van Dr. Brandes, ed. Dr. Krom; Verh. Bat. Gen. LX, 1913), met name de laatstgenoemde geschreven is in een dergelijk soort oud-Maleisch als de inscriptie van Kota Kapoer; zoodat men moet aannemen dat in de $8^{\text {e }}$ Çaka-eeuw een kolonie van (Sirvaïtische) Maleiers (nazaten van veroveraars, ò krijgsgevangenen?) gevestigd is geweest nabij Parakan; d.w.z. aan den toegangsweg uit Kẹ̣oe, over het zadel tusschen Prahoe en Seṇ̣årå, naar den Diëng! ${ }^{1}$

De derde opmerking betreft den naam van de vindplaats $K$ ot a $\mathrm{Kap}$ oer, thans een verlaten veldstreek benoorden den middenloop van de Mendoek-rivier; ongeveer tusschen dien Noordoever en de plaats die op de kaart van Stemfoort en Ten Siethoff (uit. 1898, $\mathrm{n}^{\circ}$ 11) "Pangkal Mundo", dus Pangkal(an) Menndoek, de «Aanlegplaats» der Měndoek-rivier, heet. ${ }^{2}$ Die plaatsnaam kan niet vertaald worden als "de Kamfer-veste», omdat er geen kamferboomen op Bangka groeien. Maar de naam beteekent eenvoudig «de Kalk-veste». Wanneer men zich te binnen brengt dat kalk (kapoer) en hars (gala-gala) de twee ingrediënten zijn waarmede de kielen van inlandsche vaartuigen worden bepleisterd, nadat de naden van de schepen met vezelbast zijn dicht-

1 De heer LAFeber stelt zich voor deze beide Malayiseerende inscripties afzonderlijk te vertalen en te behandelen. Naar zijne opmerking vortoonen evenzeer twee inseripties van den Diëng, n.l. die van 731 Çaka (Brandes, $\mathrm{n}^{\circ}$ II), en de ongedateerde die begint met "Hulde aan Çiwa" (Brandes, $\mathrm{n}^{\circ}$ $\mathrm{XCVI),} \mathrm{zéér} \mathrm{duidelijke} \mathrm{sporen} \mathrm{van} \mathrm{een} \mathrm{dergelijk} \mathrm{"oud-Maleisch";} \mathrm{ter'wijl} \mathrm{in}$ de vermelde meer uitvoerige en nog ter plaatse aanwezige inscriptie van Gandasoeli de Diëng met name wordt genoemd in regel 11 ("dihyang").

Merkwaardig is, dat óck in de inscriptie van Adoman, boven bij den top van den Mĕrbaboe, uit 1371 Caka (zie noot 1 op p. 148-149 hierna), een Malayisme nog voorkomt, met name jang = „die", zooals Cohen Stuart in 1872 reeds opmerkte, en Prof. Kern toen erkende (Bijdr. Kon. Inst. 3, VII, p. 278).

${ }^{2}$ Over de juiste vindplaats van dezen steen kreeg ik in 1909 te Bandoeng persoonlijke nadere inlichtingen van den vinder in 1892 , den heer J. K. vaN Der Medlen; verg. Notulen Bat. Gen. 1893, p. 106-107 en 141. Over den in 1911 door den hoofdingenieur van het mijnwezen L. J. BoERs terzelfder plaatse gevonden tweeden steen met (zeer korte) inscriptie in Wenggi-karakters, zie Notulen 1911, p. 95, en 1912 , p. 103 . De heer van der MedLen was van 1888-94 als administrateur werkzaam bij de tinwinning op Bangka, met standplaats Soengei Sĕlan; de vindplaats was „nabij de overblijfselen van een aarden wal" (Notulen, l. c.; waar v. D. Meduen's naam eehter niet blijkt). 
gebreeuwd (di pakal; verg. po eko el; òns «breeuwen» beteekent "teeren»), dan is deze Kota Kapoer in de tegenwoordige wildernis van den middenloop der Mendoek-rivier weleer niets anders vermoedelijk geweest als eene echte "Pleister-plaats», in dubbelen zin, voor Indonesische en wel vooral Javaansche, ouderwetsche zeeschepen (banawa, bangka, djong, pa$\mathrm{rahwa}, \mathrm{plawa}){ }^{1}$ waar men dus èn aanlegde èn die kielen "pleisterde", d. w. z: kale-faatte. ${ }^{2}$

\section{De Regentes-Vorstin Sìma in Kĕdoe, 674-ca. 685 A. D.}

In de Nieuwe Annalen der T'ang- of Thang-dynastie (618-906) is een zéér curieus bericht, dat op zichzelf al meermalen de aandacht heeft getrokken, o. a. van Prof. Kern en Prof. Veth, maar dat tot nog toe nimmer in verband werd gebracht met een paar andere zéér curieuze gegevens uit de inscriptie van Tjanggal (Zuid-Kẹ̣oe) van 654 Çaka $=732$ A. D.

Die Annalen, sprekend over het eiland *Ka-ling ook geheeten $\mathrm{Dja}-\mathrm{pa}$ ", dus $\mathcal{F a v a}^{3}{ }^{3}$ vertellen (naar de vertaling van GroeneveldT, Notes, 1876, p. 14 ; of herdruk, 1887, p. 139-140):

*In 674 the people of this country took as their ruler a woman of the name Si-ma. Her rule was most excellent, even things dropped on the road were not taken up. The prince of the Arabs (Ta-zi), hearing of this, sent a bag with gold to be laid down within her frontiers: the people who passed that road avoided it in walking and it remained there for three years. Once the heir apparent stepped over that gold and Si-ma became so in-

Over banawa, bangka, djong, en plawa (of palwa), zie resp. Van der Tuuk's Kawi-Bal. Wdb. IV (1912), p. 862, 1066, 435, en 246-247.

2 Ons „kalefaten", van Ital. calefatare (en calafatare), sohijnt of terug te gaan tot Arab. kalafa $=$ "met werk (kilfa) dichten", stoppen met uitgeplozen touwwerk; ò tot Lat. calefacere, het verhitten van de kiel; verg. Dozy \& Engelmann, Glossaire, 2 éd. (1869), p. 376-377. Ons „pleisteren” beantwoordt in zijn actieve beteekenis geheel aan het Indon. bedekken van de kiel met kalk en hars, het „kalken" en daarna "harpuizen”.

" "Ka-ling is also called Djava," - in de noot ook: "Djapa or Djapo" "it is situated in the southern ocean, at the east of Sumatra and at the west of Bali. At its south it has the sea and towards the north lies Cambodja" (l. c. p. p. 13 of 138),

Uit de voorafgaande noten bij Groeneveldt blijkt, dat "Sumatra" hier vertaling is van Chin. Po-li (of Pa-li), en "Bali" van Chin. Dva-pa-tan (Dwapatan). Over "Po-li" verg. noot 3 op p. 139 hiervoor. 
censed that she wanted to kill him. Her ministers interceded and then Si-ma said: "Your fault lies in your feet, therefore it will be sufficient to cut them off.» The ministers interceded again and she had his toes cut off, in order to give an example to the whole nation. When the prince of Tazi heard this, he became afraid and dared not attack her.»

Dit, op het eerste gezicht legendaire, verhaal heeft het groote voordeel afkomstig te zijn van ten deze geheel neutraal-Chineesche zijde, omtrent toestanden op Java en betrekkingen met de Tādjik's, d.w.z. Westersche Mohammedanen. ${ }^{1}$ Dat hier met *Ka-ling $=\mathrm{Kal}$ ingga, en Dja-pa (of Dja-va, Dja-po), iets anders als Midden-Java bedoeld kan zijn, wordt buitengesloten door het jaar $674 \mathrm{~A}$. D. dat door den Chin. tekst vast staat, en het jaar ca. $680(674+\mathrm{x}($ klein wel $)+3)$ dat door het verhaal wordt gesuggereerd als het jaar der wandaad van "the heir apparent», wien het de teenen kostte van zijn beide voeten. Of Groeneveldt "Ta-zi» terecht met «the Arabs» vertaalde, en of het niet juister ware geweest met «the Persians, te vertalen Jav. djaran tedji is nog thàns allereerst "een Perzisch paard" (uit Ormuz in den tijd der O. I. Compagnie als "Persiaensche paerden» verscheept), en daarna pas óók wel "een Arabisch paard, vulgo Arabier» -, zou de vraag kunnen wezen. Bedenkt men echter, dat juist met Chosroe II (591-628).de groote tijd van Perzië onder de Sassaniden-dynastie voorbij was, zijn opvolger Jesdegerd III in 636 door de Arabieren onder Chalief Omar (634-644) werd verslagen, en toen de Chaliefen-heerschappij over Perzië begon, - dan heeft Groeneveldt vermoedelijk zeer juist vertaald; en wordt er met dien "prince of Tazi», die na dat geval van ca. 680 , Midden-Java niet durfde aantasten onder zulk een model-Vorstin Sìma, wel hoogstwaarschijnlijk bedoeld de toen in Damaskus zetelende Chalief van de sinds 661 oppermachtig

1 Naar pers. meded. van den heer B. Hoetrisk, zijn de twee Chin. karakters gebezigd voor het Mandarijnsch ta-sh $\mathrm{h}$, enkel transcriptie van een buitenlandschen term, géén Chineeschen. Zie deze twee karakters in Groeneveldt's Notes (1876) p. 14, of (1887) p. 139, die ze met "Tazi" transcribeerde; en verg. over "Ta-shi" ook de litteratuurverwijzingen bijeengebracht door Dr. Schrieke in zijn proefschrift "Het Boek van Bonang” (1916), p. 9 noot 3.

De vorm "Tādjik" is van Prof. Kern in zijne rede "Over den invloed enz." (1883), herdrukt in Verspr. Geschr. VI (1917), p. 17-18, waar hij dit Chin. bericht behandelde. De volksnaam Tadjik bestaat thans nog in Turkestan voor een deel der Moh. bevolking, naast Moh. Sarten, Kirghiezen, Oesbeken. 
geworden Omajjaden-dynastie; misschien dus nog wel de eigen stichter Moeawijja (657-679). Het spreekt toch van zelf, dat een pas tot groote expansie gekomen jonge dynastie droomt van nòg veel grooter expansie; dit is algemeen dynastisch-menschelijk. Maar het zeeverkeer bleef toenmaals gaan over havens aan de Perzische golf; vooral Siraf.

Doch hoogst merkwaardig nu is, dat de twee slotstrophen $(11-12)$ der inscriptie van Tjanggal uit Zuid-Kedoe van 654 Çaka $=732$ A. D., dingen vertellen die opvallend aansluiten bij dat Chin. bericht over den Midden-Javaanschen heilstaat van 674 A. D. en later. Nadat in strophe 1 Vorst $\mathrm{S}$ a n dj a ja genoemd is als oprichter van een lingga bovenop een berg - wèlke berg, blijkt niet, maar hoogstwaarschijnlijk toch de nabije Goenoeng Woekir ' ; terwijl de vlakke steen waarop de inscriptie staat onmogelijk die ling ga kan zijn; men zie toch de mooie af beelding van den steen in Bijdr. Kon. Inst. 4, X, 1885, achter p. 138 -; nadat in strophe 7 het keiland Java» met name genoemd is als «uitmuntend in koorn [ $=$ rijst $]$ en andere zaden»; nadat in

1 De Goenoeng Woekir, in Zuid-Kĕḍoe, hoewel maar $340 \mathrm{M}$. hoog, gelegen W. ten N. van Salam en Z. ten O. van Moentilan - verg. Blad III der Oudheidkundige Kaart bij Verbeek's Oudheden van Java (1891); en zie Blad XXIII der "nieuwste topographische kaart van Kĕd̦oe, Banjoemas en Sĕmarang, schaal $1: 25.000,1898-1910$, waar de naam ten onrechte "O ek i r" wordt gespeld - droeg blijkens Hoepermans in 1865 de overblijfselen van een fraaien Cliwä̈tischen tempel; zie zijn hs. uitgegeven in Rapporten Oudb. Dienst 1913, p. 138-139, en verg. Verbeek (1891), p. 156. Dat deze G. Woekir weleer beroemd was als een der heilige bergen van Midden-Java, blijkt m.i. wel daaruit dat hij bedoeld moet zijn bij deopsomming der (inderdaad onechte, in ca. de $14^{\circ}$ eeuw gemaakte) oorkonde van Djaha uit (zoogenaamd) 762 Caka, waar hij aldus staat in de rij: Dihyang, Satasṛngga, Watoe Lampyar, Marapwi, Oemaloeng, Karoeṇdoengan, Woekir, Soembi, Soesoeṇdara. Daar Oudjav. woekir echter „heuvel, berg" beteekent, Mal. boekit (zie V. d. Tuuk's Wdb. III, 1901, p. 503a), werd bij de vertaling dit woek ir steeds bij S oembi tot nog toe gerekend, en door Prof. KkrN dan ook vertaald als "berg Sumbi" (zie den herdruk van diens opstel uit 1873 in Verspr. Geschr. VI, 1917, p. 294 en 296). Vlak aan den Oostelijken voet van het plateau van den G. Woekir ligt de desa Kadiloewih, waar de Tjanggalinscriptie gevonden werd in 1879 .

Het zou zeer veel aanbeveling verdienen op den G. Woekir, door Hoepermans beschreven als "groote bergheuvel met uitgestrekt plateau", waarop weer "eene verhoogde heuvel" (met de tempelresten), archaeologische opgravingen te doen verrichten! Hoepermans roemt die overblïfselen in 1865 herhaaldelïk als nzeer fraai". En door den datum van de Tjanggalinscriptie heeft men een kostelijk gegeven in handen omtrent den (zéér waarschijnlijken) ouderdom.

D1. 74 
strophe 8 de vorige heerscher San na wordt geloofd als een heerscher, die, "zijne vijanden onderworpen hebbende" (sic), dit "veelgeprezen eiland Java" met gerechtigheid "zeer lang" (sic) regeerde; en nadat in strophe 9 de dood van koning Sanna wordt verhaald, als een allen verbijsterend verlies; - zoo wordt "degene die daarop verrees» (str. 10), d. i. de actueele Vorst Sandjaja van het opschrift, aldus verheerlijkt (naar de vertaling van Prof. Kern, 1. c. p. 131-132; of herdruk in diens Verspreide Geschriften, VII, 1917, p. 123):

*11. De zoon van Sannāha [= Sanna; KERN], de doorluchtige, die door scharen van geleerden geëerd wordt als een kenner van den subtielen zin der boeken; een heerscher uitmuntende door dapperheid en andere deugden, die gelijk Raghu [= Rāma's overgrootvader] het gebied van verscheidene naburige vorsten veroverd heeft; Z. Maj. Koning Sañjaya ${ }^{1}$, wiens luister gelijk die der zon in alle windstreken met roem bekend is, regeert (thans) ..... [lacune!] van zijne zuster, naar recht het rijk.

12. En terwijl hij de aarde, die tot gordel den golvenden oceaan en tot borsten de bergen heeft regeert, legt het volk zonder beducht te zijn voor roovers of andere gevaren zich te slapen op den grooten weg, en bezitten de menschen, rijk in goeden naam, steeds het goede, nuttige en aangename. Denkelijk doet Kali [ = de verpersoonlijke IJzeren Eeuw, waarin wij leven; KERN] niets dan schreien, want er rest geen aandeel meer voor hem.»

Aldus het slot der inscriptie van 732 A. D. Op de meest ongelukkige plaats bevindt zich echter in strophe 11 een door uitslijting onleesbaar geworden plek van 3 korte lettergrepen en 1 lange - zie den afdruk van den Sanskrit-tekst, 1. c. p. 128, of de transcriptie in den herdruk p. 120 -, juist daar waar sprake is van de "zuster" des Vorsten, die (thans) "naar recht het rijk» regeert. Let men niet op de' jaartallen met nauwkeurigheid, dan kon allicht de vraag wel rijzen, of die Vorstin Sìma niet de "zuster» zou kunnen zijn in strophe 11

1 Over Raghu, den vader van A dja, welke laatste huwde met Indoemati en vader werd van $\mathrm{D}$ a $\rho$ a r a tha, den vader weer van $\mathrm{R} \overline{\mathrm{a}} \mathrm{ma}$, zie o. a. V. d. Tuuk's Wdb. I (1897), p. $806 a$ en $329 b$.

Dat de naam van den Jav. Vorst Sañ ay a (Sandjaja), en niet Sṛnjaya (Srĕndjaja) gelezen moest worden - zooals Prof. Kern oorspronkelijk in 1885 gelezen had, Bịjdr. Kon. Inst. 4, X, p. 129, 131, 137-, merkte Dr. Brandes op in Notulen Bat. Gen. 1886, p. 31 noot. 
bedoeld. Maar bij even narekenen blijkt zoo'n onderstelling onmogelijk. Vorstin Sìma, die onder dezen goed-Oudjavaanschen naam - sīma is «vrijgebied»; ongeveer = deça en koeța, zie V. d. Tuuk, Kawi-Balin. Wdb. III, 1901, p. $318 a$ - in 674 aan de regeering kwam, is natuurlijk de Regentes geweest voor, en zeer misschien zelfs wel de eigen moeder van "the heir apparent» van het Chin. bericht; hoewel deze laatste mogelijkheid toch wel àl te bar zou wezen voor het toch reeds zoo barre geval. Dat die Kroonprins, na de amputatie van al zijn teenen, nog tot Vorst later verheven werd, is uiterst onwaarschijnlijk; een jongere prins zal wel in zijn rechten van Kroonprins zijn getreden. En met hooge waarschijnlijkbeid was deze opvolger die daarna Vorst werd, de Sanna=Sannāha van het Tjanggal-opschrift ', die "zeer lang» regeerde; om daarna opgevolgd te worden door zijn zoon, Vorst Sa ndjaja. Aangezien de strophen $8-9$ nog vol zijn van warmen lof over Sannāha, mag men onderstellen dat hij niet zoo lang nog dood was.

Schattenderwijs zou men kunnen ramen voor de regeeringsjaren van Regentes Sìma 674-ca. 685 A. D.; Sanna =- Sannāha ca. 685 -ca. 725 ; zijn zoon Sandjaja sinds ca. 725 Vorst. Welken invloed bij des laatsten troonsbestijging die "zuster» kan uitgeoefend hebben, blijft in 't duister. ${ }^{2}$

Maar de slotstrophe 12 is 't merkwaardigste wel van het heele inschrift. Bij dien term van «bergen» teekende Prof. KERN - die in 1885 niet wist, ${ }^{3}$ dat deze beschreven steen gevonden was op een heuvel, den Goenoeng Woekir, bij het gehucht Tjanggal, in Zuid-Kẹ̆oe; bijna recht Zuid van Moentilan, en recht West van Salam - het volgende aan: "Met deze bergen zullen wel bedoeld zijn de zoogenaamde bergen van Zonsop- en ondergang,

1 Dr. Krom merkt mij op dat Skr. sa nna, behalve andere kwade dingen, ób beteekent "zich in een vertwöjelden toestand bevindend". Zou dan tòch die Jav. Vorst de geamputeerde Kroonprins geweest zijn? - Of kan S anna= Sannāba soms den Çri Widjaja der Kota-Kapoer-inseriptie van 686 A. D. (zie p. 141), ten slotte als "vijand" hebben "onderworpen" (zie strophe 8); nadat deze noverwinnende" Bangka-vorst(?) hem eerst, met zijn Maleiers, op Java-zelf was komen "tuchtigen", en "in vertwijfeling" brengen? (Krom).

'Dank zij een papierafdruk der inseriptie van Tjanggal, door Dr. Bosch aan Prof. Vogel gezonden in 1916, is het aan Dr. Krom gelukt de lacune in strophe 11 te lezen. Hij schrijft mij d.d. 4 Oct. 1917: „Er staat, zie ik wel, dat koning $\mathrm{S} a \tilde{n}$ jaya naar recht het rijk regeert, „in onverbrekelijke overeenstemming met zijn zuster"!" Dus als Mede-Regentes?

$\checkmark$ Zie toch Bijdr. Kon. Inst. 4, X (1885), p. 136. En verg. de verbeterende noot bij den herdruk dezer studie in Verspr. Geschr. VII (1917); p. 127. 
d. i. de ooster- en westerkim. In proza zou men eenvoudig zeggen: de aarde tot aan hare uiterste grenzen. In Warāhamihira's Bṛhat-Saṃhitā 43,35 heeten de Himālaya en de Windhya de borsten der aarde, terwijl de ooster- en westerkim met de lippen vergeleken worden; doch in eene inscriptie op Java betrekking hebbende kan toch bezwaarlijk aan den Himālaya en den Windhya gedacht zijni. (p. 132 noot 1 ; of p. 123 noot 3 ).

Neen, waarlijk. Maar zoodra men weet, dat deze inscriptie gevonden werd in Kẹ̣oe, dat als hoogvlakte-landschap beheerscht wordt door zijn 4 machtige bergtoppen, 2 in 't Westen: den Sẹṇåăå N. en Soembing Z., en 2 in 't Oosten: den Mèrbaboe $\mathrm{N}$. en Merapi $\mathrm{Z}$.; en als men er bij bedenkt, dat de oude Jav. naam (o. a. in de oorkonde van Djaha, zoogenaamd uit 762 Çaka) voor den thans genoemden berg Senndårå, was Soesoențara, d. i. Soesoe-n-dara of "Meisjes-borst", en dat de naam van den berg Merapi, als vulkanische, d. w. z. extramannelijke, hartstochtelijke "Vuur-berg", volstrekt zeker antiek is; voorts, dat de M $\mathrm{rbaboe} \mathrm{van} \mathrm{thans} \mathrm{weleer} \mathrm{geheeten} \mathrm{heeft,}$ naar de herkenning van Dr. KRom (zie de noot), Damaloeng ( Wildzwijn, Ever») alias O e maloe $\mathrm{ng}$, en dus eerst in jongeren tijd den thans alleen bekenden naam van "Baboe-berg" of "Zoogster-berg" (n.l. "van den vurigen Merapi») kan hebben gekregen; terwijl FRIEDERICH in 1865 door Javanen den Soembing als "Spleet-berg", d. w. z. "Yoni-berg" hoorde verklaren; zoodat dus het landschap van Keðdoe, voor ieder die daar ooit zelf verbleef, beheerscht wordt door de 4 kegelvormen van - in het N. W. beginnend, en dan, naar Hindoeschen èn Europ. trant rechtsom gaande - achtereenvolgens: de (scherpe) Meisjesborst, den (veel glooiender) Baboe- of Zoogster-berg, den Vuurberg (Merapi), en den Sleuf-berg (immers Soembing $=$ oudtijds Soembi); ${ }^{1}$ voor dien is het duidelijk,

1 Voor de volgorde der 9 bergnamen in de oorkonde van Djaha, zie reeds de noot op p. 145 hiervóór. M. i. kan met den "Watoe Lampyar", die onmiddellijk vóór den "Marapwi” staat, de Prahoe bedoeld zijn, dus de „Breede Rots" (Oudj. la mpyar wel = Jav. lĕmpar; verg. Jav. papan lèmpar $=$ "plein, open vlakte"). Voor Soesoeṇḍara verg. het nog aarzelende in V. d. 'Tuuk's Wdb. III (1901), p. 185a; de volkomen juiste verklaring van dezen naam als "Meisjes-borst" gaf Prof. Kern in Bijdr. Kon. Inst. 5, IV (1889), p. 298: soesoe + n + d̦arā (=rarā). Dat de „Satașrngga", die tusschen den Dihyang en den Watoe Lampyar in staat, = Jongjav. $\mathrm{S}$ oetårĕng $\mathrm{g} \mathfrak{a}=$ de $\mathrm{M}$ oerja is, en de Karoeṇḍoengan = Jongjav. 
dat het begin van strophe 12 bloemrijke beeldspraak is voor zichtbare dingen. Met de omschrijving van 's Vorsten Sandjaja's eigen rijksgebied ${ }^{1}$ als "de aarde, die tot gordel den golvenden

Karoengroengan $=$ de Oengaran is, heeft Prof. KRRN aangegeven in resp. Bijdr. Kon. Inst. 3, VIII (1873), p. 227, en 5, IV (1889), p. 298.

Slechts de „Oemaloeng", opgenoemd tusschen den Marapwi en den $\mathrm{K}$ aroeṇִ oengan, blijft dan nog een raadsel; het is echter aan Dr. KRoM gelukt vast te stellen, dat dit de oude naam moet zijn geweest voor den Mĕrbaboe. Eerstens merkte hij mij op, dat de bergnamen Oemaloeng en Damaloeng feitelijk dezelfde zijn (zie V. d. Tuuk's Wdb. I, p. $300 b$ i. v. aloeng; en II, p. 520-521 i.v. damalung, waar de Damaloeng. wordt vermeld nà den Diëng, "Dihyang"); en dan vooral, dat de inscriptie uit 1371 Çaka, thans te Leiden, van de desa Adoman (of Ngadoeman), hoog op de N.helling van den Merrbaboe (Kawi-Oorkonden ed. Cohen Stuart, 1875, $\mathrm{n}^{\circ}$ XXVII), juist verheerlijkt eenen „oppersten berg" (wukir hadi), dien Cohen Stuart reeds in 1872 (Bijdr. Kon. Inst. 3, VII, p. 277, 279) las als ò "Damaloeng" of "Oemaloeng", doch dien Brandes definitief als D a maloeng gelezen heeft (Oud-Jav. Oorkonden, 1913, p. 266). Vax Goens in 1656 schrijft "Marbâbou"; en noemt den Mĕrapi : Belirangh", dus "Zwavel". berg; zie Bijdr. Kon. Inst. 1, IV, 1856, p. 309, 311.

Er mag dus gezegd, dat, indien men voorloopig het vermoeden dat de Watoe Lampyar = Prahoe is wil aanvaarden, in de eerste 2 (Diëng en Moerjå) de twee Heiligste Bergen van Midden-Java genoemd zijn, in de 3 volgende (Prahoe?, Mĕrapi, Mĕrbaboe) die van den $2^{\text {on }} \mathrm{rang}$, en in de 4 volgende (Oengaran, Woekir, Soembing, Sěṇḍ̊å) die van den $3^{\text {en }}$ rang; deze laatste volgens het pradakshiṇa ("reehtsom-draaien") opgesomd.

Welke bergen echter bedoeld kunnen zijn met de in dezelfde oorkonde van zgn. 762 Caka dan dadelijk volgende andere 5 bergnamen: Koedjatan, Walambangan, Goelasing, Langoenoe, Patoenggwan, blijft een groot raadsel. Of men wel bij "Walambangan" aan den landsnaam Balam. bangan mag denken, zooals Prof. Kern in 1873 l. e. deed, is zeer de vraag.

De passage bij Friederich over den Soembing uit 1865 - op welke Dr. Krom mij attent maakte - luidt: "Het woord Soembing beteekent een spleet, (Engl. a gap), een andere(n) naam is aan mij niet opgegeven. Daar echter de berg naar de boven zich bevindende Joni-achtige spleet genoemd is,$\ldots$ hebben wij eene anduiding dat voornamelijk die spleet of Joni in aanmerking kwam" (Tijdschr. Bat. Gen. XXIII, 1876, p. 96-97). Jong-jav. s oembi is volgens het Jav. Hwdb. 1901, I, p. $870 a=1^{\circ}$. een soort weverskam, $2^{\circ}$. een stut (voor het roer), en $3^{\circ}$. tong van een gesp, waarin dus ook het begrip "spleet- of sleuf-vormig, gaffel-achtig" uitgedrukt bleef. Dat de berg Sĕṇdårå zijn naam zou danken aan den aldaar groeienden boomheester Anaphalis javanica Sch. Bip., waarvan de composiet-bloemen wel „de Javaansche Edelweiss" worden genoemd (zie Veth's Java, $2^{\text {sen }}$ druk, III, 1903, p. 456) is natuurlijk onjuist; het omgekeerde is het geval; deze bergheester heet naar dien berg, en wordt ook wel sĕndårå en sindårå gespeld (verg. 't Jav. Wdb. 1901, II, p. $844 a$ in de Bijvoegsels en Verbeteringen).

1 Om deze Oudjav. "kern des rijks" (Jongjav. nagaragoeng) heen, bevonden zich, blijkens de Annalen derzelfde T'ang-dynastie, 28 provinoies: 
oceaan en tot borsten de bergen heeft », wordt niets anders bedoeld als wat in bloemrijk Hollandsch *de tuin van Java s heet,

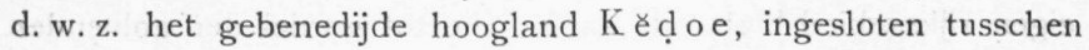
zee en zee, en tusschen kegelberg en kegelberg, met den "Goden-berg" (Di i-hyang, Diëng) in 't uiterste N. W.

Maar nòg merkwaardiger is dat andere, dat dan volgt over dit, inderdààd wonderschoone, hoogland Kẹ̣oe: daar «legt het volk zonder beducht te zijn voor roovers of andere gevaren zich te slapen op den grooten weg». Want hier hebben we in levenden lijve het Chineesche verhaal, dat geen sprookje meer blijkt te kunnen zijn, maar tot op zekere menschelijke hoogte heusche waarheid moet zijn geweest in het heerlijke hoogland Kedoee tusschen 674 en 732 .

Was het dan zoo'n wonder, dat juist in zulk een aardsch paradijs, waar een halve eeuw lang door de Regeerders naar een heilstaat werd gestreefd.... een goede halve of een heele eeuw later de Boroboedoer kwam te verrijzen, dat grootsche monument voor den $\mathrm{M}$ a h $\bar{a} \mathrm{k}$ a r o e ṇ a, den Grooten Ontfermer? 1

Zoo werpt het Chin. bericht omtrent Vorstin Sima in 674 een licht vooruit naar de mogelijkheid der wording van dit verheven bouwgewrocht in het begin der $9^{\mathrm{e}}$ eeuw.

Persoonlijk wil ik in dit verband mijn sinds lang gevestigd vermoeden niet terughouden, dat de Mendoet, met zijn buitengewone oriëntatie (naar het N. W., dus naar Voor-Indië), met „On different sides there are twenty eight small countries, all acknowledging the supremacy of Djava"; dus 28 Mantjanagara (Groenevoldt, Notes, 1876 , p. 13 ; of 1887 , p. 139 ). In het geheel waren er toen, volgt aldaar: "thirty two high ministers"; d.i. natuurlijk 4 (voor Këḍoe) +28 (voor de Buitengewesten), en van deze 32 was de "Da-tso-kan-hiung" = Datoe Kangdjĕng "the first”. Die van de Nagaragoeng worden in de Annalen der $2^{\text {de }}$ Soeng-dynastie (960-1279 A. D.) dan nog special met hun (verhas. pelden) titel vermeld als: ${ }_{\text {}}$ four functionaries, called Lo-ki-lien [= Rakryan; Kern], who manage together the affairs of the state, just as the ministers in China" (ib. p. 16 of p. 143); haast wel zeker de uit de Oudjav. Oorkonden van vóór $950 \mathrm{~A}$. D. meestbekende $4 \mathrm{mahāmantri's,} \mathrm{n.l.} \mathrm{de} \mathrm{Rakryan}$ mapatih, R. hino, R. haloe, en R. sirikan; welke - vermoedelijk!weer gelijk te stellen zijn met de sinds Senapati's tijd (ca. 1587) 4 hoogste waardigheidsbekleeders in Mataram: 1. Raden Adipati, 2. Pangeran Adipati (Anom), 3. Pangeran Ngabehi, en 4. Pangeran Lor ing Pasar (=Senapati?). Over Oudjav. hino, haloe, en sirikan, zie resp. V. d. Tuuk's Wdb. I (1897), p. $22 b, 259 a$, en III (1901), $68 b$.

1 "Mahäkaroeṇa" is de speciale bijnaam van A walokitę̧wara (=Padmapāni $=$ Lokanātha), maar kan ook van den Boeddha worden gebexigd (pers. meded. Dr. Krom). 
zijn buitengewone 3 hoofdbeelden (Gautama + Awalokiteçwara + Mandjoeçrī), met zijn buitengewone eer aan het beeld der Vrouwe Hāritī boven het beeld van den Heere Koewera op de twee binnenste intree-wanden gebracht, immers resp. gebeeldhouwd aan de N. O.- en de Z. W.-zijde (dus resp. Rechts en Links van het hoofdbeeld), met zijn buitengewoon-klassieke en dùs antiekHindoesche architectuur en plastiek ' , met zijn Awalokiteçwaravoorstelling op den achter-buitenwand, met zijn Godinne- hoofdbeelden op rechter- en linker-buitenwand, een Graftempel is; en dat wel niet van een Vorst, doch van eene Vorstin.

En onwillekeurig, zij het vragenderwijs, komt ons daarbij de naam van de Regentes-Vorstin Sīma weer op de lippen; ook al zou dan deze tempel eerst ca. 50 à 100 jaar na haar dood te harer eere zijn opgericht.

\section{Rijksbestierder-Vorst Daksha, en Tjandi Prambanan; ca. 820-840 Caka.}

- In zijne beschouwingen omtrent eden overgang van het politiek overwicht van Midden- naar Oost-Java, samengaande wellicht met den ondergang der Midden-Javaansche staten», blijkend door "de inscriptie's uit de negende çaka-eeuw ", heeft Dr. KROM in 't Rapport Oudheidk. Onderz. over 1911 (Batavia, 1912, p. 12-15) aangetoond, dat de van (minstens) 820-ca. 832 Çaka als Rijksbestierder en van (hoogstens) 832-841 als Vorst regeerende $\mathrm{Daksha}$ (Dakșa), deze beide waardigheden heeft vervuld over zoowel Midden- als Oost-Java. Rijksbestierder was hij onder het koningschap van Vorst Balitoeng, die zetelde in OostJava, waarschijnlijk zelfs te Blitar, van minstens 820 tot uiterlijk 830; Rijksbestierder nog steeds onder den op dezen in 830

1 Men leze hierbij nog eens de zeer gewichtige inleidende bladzijden van Dr. Brandes bij zijne studie "De hoofdbeelden op de voorsprongen van den teerling der Tjandi Mendoet (Padmapani, Tara, en Bhrekutitara)" in Notulen Bat. Gen. 1902, Bijlage XIII; en daarin met name de zinsnede over de ningeestige distributie van het ornament aan dezen tempel, die het in dit opzicht misschien nog wel wint van de Baraboedoer" (p. CXIX). Ik dank het aan den Heer B. DE $\mathrm{H}_{\mathrm{AAN}}$, thans als adjunct-bouwkundige naar Java vertrokken, dat hij, bij het samen bezien der foto's van den Oudheidkundigen Dienst, mij in Jan. 1918 door zijne opmerkingen ten volle heeft overtuigd, dat de Mĕndoet als bouwgewrocht op Java wel de méést-harmonische, edelstgecomponeerde tempel moet heeten. - Over de beolden aan de buitenwanden van den Mĕndoet, zie het belangrijk opstel van Dr. Kros hierachter. 
gevolgden Vorst Mahāçambhoe, die echter nà 832 Çaka niet meer in de (tot nog toe bekende) inscripties voorkomt; maar in dat jaar 832 C.. wellicht, doch anders zeker in 837 C.. is Daksha zelve Vorst geworden, om echter reeds in 841 Ç. vervangen te blijken door Vorst Tloḍong, die tot Rijksbestierder had den befaamden Mpoe Siṇdok, welke laatste in ca. 850 Çaka $=928$ A. D. zelf als Koning optreedt en de groote periode van Oost-Java's opperheerschappij inleidt. '

Rijksbestierder, daarna Vorst, Daksha is aldus een overgangsfiguur geweest op politiek gebied; zelve schijnt hij zijn hoofdverblijf steeds te hebben behouden ste Mẹang in het land van Mataram» (i Mḍang i bhūmi Mataram), zooals de sacramenteele vorm in de oorkonden blijft luiden, nog lang nadat de hoofdzetel van Java's Oppervorst reeds uit het gebied van $\mathrm{M}$ a t a r a m-proper, samenvallend vrijwel met het huidige Jogjasche landschap Mataraman, alias Mataram (tusschen de rivieren Opak en Prågå), voorgoed was overgebracht naar Oost-Java.

Doch ook op geloofs-gebied was Daksha een dubbel-natuur; alleréérst warm Çiwaiet, maar daarnaast een overtuigd Boeddhist; de twee gelooven samenvattend in zijn synkretistische ziel, zooals $3 \frac{1}{2}$ eeuw later in Oost-Java Vorst Kerrtanagara, alias Çiwaboeddha (1268(?)-1292 A. D.) zou doen; misschien ook beiden wel met die deels religieuze, deels wereldwijze, overtuiging, dat het voor een Jav. Vorst verstandig was twéé Hemel-Heeren te dienen. Waren niet hun onderdanen verdeeld in een Cliwaïtische volksmenigte plus deftige oud-geloovigen, en in Boeddhistische «hoogere kringen, plus nederiger intellectueele nieuwlichters?

Als Rijksbestierder blijkt dit feit van Daksha niet uit de tot nog toe bekende oorkonden. Maar nauwelijks is hij Oppervorst (Ç ri Mahārādja), of, in een nieuwe jaartelling (nimmer daarvóór en nimmer ook daarnà door andere Vorsten op Java gebruikt!), geeft hij, een jaar na mekaar, twee stichtingsoorkonden in de onmiddellijke buurt van Prambanan, die op Javaanschoudheidkundig gebied allergewichtigste unica zijn. Voor het nu volgend betoog wordt natuurlijk gebruikt de door Dr. KROM in 1913 bezorgde uitgaaf der nagelaten transscripties van wijlen Dr. BRANDES, "Oud-Javaansche Oorkonden" (Verh. Bat. Gen. LX).

In de cjaartelling van Z. M. Sandjaja jaargetal 693» (s a ṃwat

1 Duidelijkheidshalve gebruik ik liever den term „Rijksbestierder”. dan dien yaṇ „Minister", welkẹn laatsten Dr, Krom t. a. p. bezigt, 
Çrī sa ñjay a wa rşātîta 693), geeft hij, onder aanroeping van Cliwa + Doerga (rudradurgga), onder zijn vollen titel Cri Mahāradja Dakshottamabāhoebadjra-pratipaksha$\mathrm{kshaja}$, een handvest.... ten gunste van een reeds bestaand Boeddhistisch klooster (darmma kawikoean) te Timbanan Woengkal, alwaar ‘voornamelijk een godin ( $b$ h a țā $r i)$ vereerd werd, (Brandes, 1.c. p. 53). $\mathrm{Nu}$ is deze steen in begin 1864 - zooals N. W. HOEPERMANS bescheidenlijk getuigt in het netschrift zijner gezamenlijke rapporten tusschen 1864 en 1867 uitgebracht aan zijn chef, Dr. Friederich; uitgegeven door Dr. Krom in Rapporten Oudheidk. Dienst N. I. over 1913 (Batavia-'s Grav. 1914, p. 73--372) - egevonden bij de dessa Gata nabij de bergrug Prambanang, thans $[=1864]$ aanwezig op de pasang grahan te Prambanang; niet verre van af de bergrug Prambanang, bij de dessa Gata, gelegen het zuiden in, van af Prambanang, wil men, dat vroeger eene tempel heeft gestaan, (1. c. p. 237). Doch dat Hoepermans zelf de vinder was blijkt uit wat FRIEDERICH over dezen steen e. a. mededeelde in Tijdschr. Bat. Gen. XXIII (1876), p. 67-68, en verg. er p. 42. Wat Hoepermans echter in zijn militair stijltje *Gata doopte, is ten rechte G e tak k, voluit Gětak sari (d. i. "Mooi-schreeuw»), een desa op 1 paal $Z$. van Prambanan; op de Residentie-kaart van Jogjakarta (1876) "Gatak sari, geheeten, op de kaart van IJzerman's "Beschrijving der oudheden enz.» (1891) zeer goed "Getak sari»; op de kaart bij Dr. Verbeek's *Oudheden van Java” (ook 1891) en in zijn tekst p. 178-179 verwonderlijk foutief "Gata,, wat dan toch Gåtå zou moeten worden uitgesproken; te verwonderlijker omdat Dr. Verbeek op zijn heele kaart van 5 bladen stelselmatig heeft getracht naar goede spelling. $\mathrm{Er}$ mag dus met bijna volle zekerheid beweerd, dat de desa "Timbanan woengkal, der inscriptie van «693 Sandjaja, met haar Boeddhistisch klooster in 's Vorsten Daksha's tijd, \pm 837 Caka $=915$ A. D., niets anders was als de tegenwoordige desa G ̌tak sari, op een kwartier loopens Z. van Tjaṇdi Prambanan; terwijl vermoed mag worden dat daar dezelfde Boeddhistische Godin, dezelfde Tārā voornamelijk vereerd werd, als aan welke reeds in 700 Caka de beroemde Tjaṇdi Kalasan was toegewijd geworden, die weer op een half uur loopens van Gětak sari W. ten Z. ligt. ${ }^{1}$

' Dr. Krom ziet in het „ḍarmma kawikua n" dor inscriptie van Sandjaja 693 géén Boeddhistisch klooster; het woord dharmma, merkt hij mij op 
Maar véél belangrijker nog is de tweede oorkonde in Sandjajajaartelling, het jaar nà de schenkings-akte aan 't Boeddhistisch klooster te Timbanan woengkal uitgevaardigd; n. 1. in « Z. M. Sandjaja jaar 694, (çri sa ñ ja y a warsā 694). Tot nog toe was echter onbekend, wanneer en waar deze inscriptie gevonden was.

Dr. Brandes catalogiseerde haar het eerst in Groeneveldt's Catalogus Archeol. Verz. (1887), p. 373-374, zònder eenige litteratuurverwijzing (dus ook zonder jaar van aanwinst), als D. 6, en met "Afkomst onbekend, Zoo komt zij dan ook niet voor in den tekst bij Verbeek (1891); alleen wèl in diens Chronologische Lijst vóóraan, p. 8, als "Steen Mus. N 6 - 694 Sandjaja Midden-Java», waaronder volgt de «Steen Mus. № 36 (van Gata bij Prambanan) - 69.[sic] Sandjaja - Jogjakěrta», terwijl bij die 2 onder elkaar geplaatste jaartallen "694 Sandjaja» en *69. Sandjaja * met een accolade staat: " \pm 850 Caka». De jaarcijfers nu in deze lijst bij Verbeek, zijn alle van Dr. Brandes (verg. o. c. p. 6 der Inleiding); en de toevoeging "Midden-Java , bij den eersten is gewis ook van hem, in verbetering van het "afkomst onbekend" uit 1887. Doch thans durf ik beweren, dat deze steen D. 6 in 1868 naar Batavia door den resident van Jogja werd overgezonden; immers, dat hij de derde was van de "drie beschreven steenen * die in dat jaar, alle drie als geschenk van RADEN SALEH, naar 't Bataviaasch Genootschap gingen (zie Notulen Bat. Gen. VI, 1868, p. 60 en 67), terwijl daarvan één de beschreven steen van Getak sari (vulgo "Gata»), en de tweede de steen-Kðloerak was, resp. D. 36 en D. 44 van Brandes' Voorloopigen Inventaris in Groeneveldt's Catalogus uit 1887. Het *?» dat ik dan ook in 1909 plaatste bij D. 6 in de kolom der jaren van "Aanwinst in de bijgewerkte "Lijst der beschreven steenen (D. 1-116), van het Bataviaasch Genootschap (Notulen B. G. XLVII, 1909. p. LXXVII-LXXXV), durf ik dus thans gerust vervangen door «1868», onder verwijzing naar de Notulen van dat jaar.

Aan de kolom der "Herkomst" had ik toen in 1909 echter als conjectuur bij D. 6 reeds toegevoegd: "Tadji (even beO. Pram-

wordt in de Oudjar. Oorkonden gelijkelijk gebruikt roor een klooster van Boeddhisten of Çiwaieten (verg. de aanhalingen bij V.d. Tuuk, II, p. 422), en hoewel wiku=bhikṣu een zuiver-Boeddh. term is (verg. V. d. T., III, p. 502), behoeft dit woord de samenstelling nog niet tot een Boeddh. klooster te stempelen. Voorts schrijft hij mij: „Bhaţāin zonder meer is in de eerste plaats $\mathrm{P} \overline{\mathrm{ar}} \mathrm{wat} \overline{\mathrm{i}}=\mathrm{Durg}$ ã. Waarom hier niet? Ik vind die oorkonde zuiver Çiwaïtisch." 
banan)?"; zijnde dit gegrond op het "Tadji goenoeng* dat in den aanhef der inscriptie op een allermerkwaardigste wijze voorkomt.

Immers, zooals Dr. Brandes het in 1887 bij Groeneveldt reeds mededeelde, was het eene: *Oorkonde waarbij, zooals het schijnt, door Rakryan i Sigaḍiri (?) de banua ni Taji gunung tot sîma [=vrijgebied; zooveel als thans perrdikan-desa] wordt verheven, omdat daar vroeger Çrî Sañjaya gelegerd was geweest (s a n g hyang wungkal sîma susuk kulumpang çiniwi ri tarub nguni çrî $S$ a ñ a y a naran at tha haji bali t ua çrî Lowanna); de steen schijnt oorspronkelijk te zijn opgesteld op een sawah (d̂̂ ni sawah)» (1. c. p. 374). Nu we echter de volledige transcriptie door Dr. BRANDEs van deze oorkonde bezitten in de uitgaaf van 1913 (p. 55-57), zoodat ook zij die het Oudjavaansch niet machtig zijn (gelijk schrijver dezes) eenige gemakkelijk daaruit op te merken gegevens in verband vermogen te brengen met eenige dergelijke gegevens in de daarvóór (p. 53-54) getranscribeerde oorkonde van 693 Sandjaja, kunnen diverse belangrijke feiten uit beide in onderlingen samenhang worden gebracht. Bovendien is Dr. KROM zoo vriendelijk geweest, het hieronder ten deze volgende aan de teksten der beide inscripties te toetsen.

De, met den vollen naam van Mahārādja Daksha uitgevaardigde, oorkonde van 693 Sandjaja, onder aanroeping van Ciwa + Doerga, ten bate van het Boeddhistisch klooster weleer te Gřtak sari (= Timbanan woengkal; zie hiervóór), noemt, na die volle titulatuur van den Oppervorst (r. 4-5), diens «bevel» (a j ñ a; r. 3-4) als "neergedaald op (d. i. gegeven aan) den Heere Rijksbestierder, op (de Mantri's) Haloe, Sirikan, Wěka, en den Heere Goeroenwangi, en op (een) Saměgat" (tumurun i rakryān mapatih [.] i halu, sirikan, wka, muang rakryān gurunwangi, muang i samgat; r. 5-6).

Doch de oorkonde van 694 Sandjaja, ten bate van het vrijgebied te "Tadji Goenoeng, (sīma i taji gunung; r. op smallen linkerkant) - dat straks nader zal bewezen worden, niets anders te kunnen zijn als de historische desa $\mathrm{Tadji}$, een eindje beO. Prambanan, de antieke «tolpoort, tusschen het landschap Mata$\operatorname{ram}(\mathrm{an})$ en het landschap Padjang -, begint met «Hulde aan Ciwa, Hulde aan Boeddha» (n a m ççiwāya namo buddhāya; r. 4), zegt dan, na de dagteekening, dat *de grond van Tadji. 
Goenoeng afgepaald is geworden als vrijgebied door den Heere Grootminister en den Heere Goeroemwangi [sic] en (een) Samegat (banua ni taji gunung sinusuk șima dai rakryan mahāmantri muang rakryan gurumwangi muang s a m ge t; r. 5-6), enz. enz., een en ander «als Jonste van den Heere te Sigadiri» (panganugraha rakryan i sigaḍiri; r. 20 voorkant). En dat hier "rakryan mahāmantri, terecht met het enkelvoud werd vertaald, blijkt uit het vervolg der inscriptie op den achterkant, r. 25, waar wéér van dienzelfden $\mathrm{maha}$ $\mathrm{mantri}$ [sic] en van rakryan gurubangi [sic] gesproken wordt, terwijl dan in r. 29 nogmaals wordt heengeduid naar die "twee Heeren» (rakryan kāli h). De Mahāmantri der oorkonde van 694 Sandjaja is dus wel zeker precies dezelfde als de Mapatih der oorkonde van 693 Sandjaja; en niet b. v. een der Mantri's Hino, Haloe, Sirikan, Weka, of hoe deze hoogwaardigheidsbekleeders - ongeveer: $N \bar{a}$ ja k a's - al zoo geheeten mogen hebben.

Het verdere van deze twee zeer belangrijke oorkonden - door hun jaartelling niet minder zeldzaam, dan opmerkelijk door hun godsdienstig synkretisme - moet overgelaten worden aan kenners van het Oudjavaansch. Omtrent de tweede heeft Dr. Brandes reeds gewaarschuwd, dat $\mathrm{zij}$ is in een zeer onduidelijke taal en eigenaardig gespeld ; ; en er opmerkzaam op gemaakt (het eerst reeds in Tijdschr. Bat. Gen. XXXI, 1886, p. 250 noot) dat de Dihyang = Diëng er in genoemd wordt; terwijl ik mijnerzijds nog toe kan voegen, dat de eerste 3 regels, die aan de transcriptie van Dr. Brandes ontbreken, naar persoonlijke inlichtingen van wijlen Prof. KERN in 1913, niet het begin der inscriptie vormen, maar veeleer een toevoegsel zijn, wegens gebrek aan plaats, op den aan alle vier kanten dicht beschreven steen bijgeschreven; men zie daarvoor nader de noot hieronder. ${ }^{1}$

1 D.d. 20 Sept. 1913 schreef mij Prof. KERN, nadat ik hem een paar speciale foto's en een papierafdruk van de errste 3 regels had kunnen toezenden, op mijn verzoek door den heer J. P. Moquerte te Batavia gemaakt:

"Van het drietal regels aan 't begin van de inscriptie uit Tadji is weinig terecht te brengen. Het schrift is knoeierig en daarenboven heeft de steen daar veel geleden. Ik laat nu mijne lezing volgen. De onzekere letters heb ik onderstreept. Om

1. pangasĕan nikanang sīma de ni-i Dihyang pasajya - -

2. - ni po mā $5 \because$ sang hyang i Dihyang sa - sajya -

3. si $r a-$ po - - - ha $g i$ - - - - "

Toen ik hem nader vroeg, of het mogelijk was dat dit het slot kon zijn der heele inseriptie, antwoordde Prof. Kern mij d.d. 29 Sept. d. a. v, : 
Maar waar in beide oorkonden de Rijksbestierder + Rakryan Goeroenwangi (d. i. "Heere Geurige Wildernis»; in de $2^{\mathrm{e}}$ oorkonde, zooals boven reeds bleek, eerst verhaspeld tot * $\mathrm{Gu}$ rumwangi», en daarna tot "Gurubangi») een rol spelen, bij de eerste in de schaduw van $Z$. M. Vorst Daksha, bij de tweede als protagonisten voor "den Heere te Sigadiri, - wie deze dan ook geweest moge zijn - ; waar in beide de nimmer meer gebruikte Sandjaja-jaartelling voorop staat; waar in beide Ciwa + het Boeddhisme gehuldigd worden; daar durf ik de sluitrede opstellen: Vorst Daksha der eerste moet dezelfde zijn als de Opperheer van den "Heere te Sigadiri" der tweede.

Twee onderdeelen van de tweede oorkonde moeten echter nu nog afzonderlijk besproken.

Kan met goed vertrouwen in het " $\mathrm{Tadji}$ Goe noeng " gezien worden de tegenwoordige halfvergeten, maar in den tijd der Compagnie nog welbekende historische desa $\mathrm{T}$ adji, aan den Z. kant van den grooten weg tusschen Prambanan en Klațen, aan den W. oever van de kali Koengklangan - men zie de speciale "Kaart van Prambanan», 1:50.000, op Blad III van Dr. Verbeek's Oudheidkundige Kaart (1891) ${ }^{1}$ - , en dus op de oude grens van de landschappen Padjang en Mataram-proper,

"Tegen de veronderstelling dat de 3 regels aan 't boveneinde van den steen eigenlijk het slot der geheele inscriptie bevatten, bestaat het bezwaar dat ze bekroond zijn met de lettergreep $\mathrm{O} m$, die anders altoos aan 't begin van een stuk staat. Doch het zou wel een afzonderlijk toevoegsel kunnen wezen, waarvoor aan 't einde geen plaats meer was. Misschien staat po ma voor Posya $\mathrm{ma} s a$ in den aanhef der inscriptie, en duidt 5 aan twee dagen na Posya māsa 3 (tritīya), zoodat de inboud der 3 eerste regels, een toevoegsel, betrekking heeft op iets dat 2 dagen later plaats had."

In deze inscriptie van Tadji worden ook reeds $\mathrm{K}$ a lang's genoemd; evenals in de nog oudere van 808 Çaka uit Kĕdoe (Brandes, l.c. p. 21).

1 De Residentie-kaart van Soerakarta (1876), berustend op topographische opmetingen tusschen 1861-66, plaatst $\mathrm{Tadji}$ aan den Oost-oever van de Koengklangan; de naam Bedji komt bij die desa, Noord van den grooten weg, niet voor. Men weet echter, dat de van de Z.Z. O. helling van den Mĕrapi komende rivieren en stroompjes herhaaldelijk hun bedding verleggen in het losse vulkanische zand; reden, waarom sinds ca. 1900 verscheiden van deze waterloopen door de belanghebbende landhuurders binnen dijken en betonbemuringen zijn ingesloten en genormaliseerd geworden. In 1889 lag Tadji zeer beslist aan den West-oever, en de benoorden daarvan zich bevindende desa Bedji, met den Goenoeng Kĕmpoel, evenzeer. Uit de Reijsbeschrijving van Van Goens, in den hoofdtekst genoemd, blijkt niet waar in 1654 (toen hij de Mataramsche hofreis deed) de tolpoort "Tadie" lag ten opzichte van de daar vermelde "schoone rivier"; wèl vertelt hii van de overstroomingen van deze rivier in den regentijd. Zooals men weet, is de Koengklangan de voorname bron-rivier van de Děngkeng, en daardoor van de Solo-rivier of Bẻngawan. 
“de poort Tadie» van VAN GoENs' allermerkwaardigste "Reijsbeschrijving van Samârangh nae Matâram, uit 1656(Bijdr. Kon. Inst. 1, IV, 1856 , p. 307-350), als zijnde toenmaals "den rechten ingangh tot den Matâram ende des Sousouhounang's hoff» (p. 311)? Van het oogenblik af dat ik deze desa in 1889 van Jogja uit bezocht, heb ik daaraan nimmer getwijfeld. Immers, aan den overkant van den grooten weg, ligt de desa Bedji («Waterwel»), die met de desa Tadji («Hanespoor-vlijm») één geheel uitmaakt, en welke alleen door den grooten weg van elkaar gescheiden zijn; en in die desa Bedji nu ligt de Goenoeng Kermpoel, waaromtrent ik in de Notulen Bat. Gen. XXXI, 1893, p. 141-142 eenige mededeelingen deed, en een schetsje gaf van de 12 oempak's (neuten) aldaar, die gewis in ouden tijd een monumentale ontvangst-pendopo schraagden. Waar dus in het territoir der antieke desa Tadji zich nù nog "een verhoogde plek" bevindt, die ter plaatse "Goenoeng [sic] Kempoel » heet, behoeft er nauwelijks aan getwijfeld, of die desa Tadji van thans kan in oud-Mataramsche tijden zéér wel "Tadji goenoeng * als volledigen en officieelen naam hebben gedragen; terwijl thans nog "een nandi en eenige andere Siwaitische overblijfselen» bij dien Goenoeng Kempoel verspreid liggen (1. c. p. 142).

Een geheel andere vraag is deze: kan de "Crī Sandjaja, der jaartelling waarin de beide oorkonden van Getak sari en van Tadji (goenoeng) vervat zijn, dezelfde wezen als de Çrī Sandjaja, omtrent wien de tweede oorkonde getuigt, dat daar te Tadji het desa-gebied (banua) tot vrijgebied ( $\mathrm{s} \overline{\mathrm{m}} \mathrm{a}$ ) werd verheven - tot perdikan-desa dus werd gemaakt —, omdat er "vroeger» (nguni) Çrī Sandjaja "gelegerd was geweest» (zooals Dr. Brandes in 1887 çiniwi ri ta r ub vertaalde, zie reeds hiervóór p. 155; letterlijk, naar pers. meded. van Dr. Krom: "vertoefde in een tent»; dus in Vorstenlandsch-Javaansch van thans: makadjangan, d. i. "kampeerde onder een kadjang-dak", verg. het Jav. Hdwdb. 1901, I, p. $527 a$ )?

Dit nu is, zoo te zeggen, onmogelijk! Immers, daar 693 Sandjaja (het jaartal der $1^{\mathrm{e}}$ oorkonde in die vreemde jaartelling) ongeveer gelijk moet staan met 837 Caka (toen Daksha gewis Vorst was, blijkens de inscriptie van dat jaar uit Singasari, D. 87 in 't Museum te Batavia sinds 1893; verg. reeds Brandes in 1887 bij Groeneveldt, p. 359), dus 915 A. D., zoo moet 0 Sandjaja ongeveer $=144$ Caka $=222$ A. D. zijn. Is het nu aannemelijk, 
dat een Javaansch Vorst bijna 700 jaren na dato een feit zou gedenken, dat dan toch in $c a .223 \mathrm{~A}$. D. ( $2^{\mathrm{e}}$ oorkonde) moest hebben plaats gehad in het hart van Midden-Fava? Terwijl we tot nog toe zelfs niet de minste zekerheid bezitten, dat er reeds in de $3^{\text {e }}$ eeuw na Chr. eenige Hindoe-dynastie ergens op Java, laat staan in Midden-Java, heerschende was!

Het antwoord moet kortweg ontkennend luiden.

Neen. De éénige mogelijkheid,' gegrond op de tot nu toe bekende oude Jav. oorkonden, is: dat hier door Vorst Daksha in ca. 838 Çaka, een feit werd herdacht uit het leven van Vorst Sandjaja van Midden-Java, den oprichter van een lingga op een 'berg, (wel den Goenoeng Woekir, beter den Woekir of 'Heuvel», even beW. Tjanggal in Zuid-Kðdoe, in 654 Caka; zie hiervóór sub 3); d. w. z. een feit, toen een kleine 200 jaar geleden. Dàt kan! Maar aan den anderen kant, is het instellen van eene "Çrī Sandjaja»-jaartelling door Vorst Daksha in ca. 837 Çaka, en daarmede het op zijde schuiven van de Cakajaartelling die de Keḍoe-Mataram'sche Vorst Sandjaja zelve in 732 A. D. had gebruikt, een daad van welbewuste, veel-zeggende opzettelijkheid. Al moge de vlieger der Sandjaja-jaartelling dan ook niet zijn opgegaan binnen het Jav. gebied - meer dan 2 maal is hij niet opgelaten, voor zooveel we thans weten; een jaar na mekaar - , deze verrassende innovatie van Vorst Daksha wil in wat gewoner menschentaal zeggen: "Ik, Opperkoning aller Javanen van Oost en West, stel eene nieuwe aera in, tot hulde aan "Sandjaja den Gelukzalige» uit den oertijd, in het land onzer herkomst, Voor-Indië! En de Çaka-jaartelling, heden ten dage op Java in zwang, verdwijne! Zus is mijne Wil.,

Hoogst opmerkelijk in dit verband blijft, dat de genoemde Vorst Sandjaja de éénige is van alle heerschers over het antieke Midden-Java van vóór 950 A. D., wiens naam niet totaal verdwenen is van Midden-Java, en zelfs er voorkomt bij een zéér opmerkenswaarde plek. Immers, beZ.O van Salatiga, sin den bovenloop der kali Sindjaja ten zuiden van desa Tingkir (aldus Verbeek, Oudheden van Java, 1891, p. 96) kwam, bij de bronnen dier "kali Sěndjojo» (p. 97; bericht uit 1887) weleer “een vorstelijke badplaats» voor; alias "een bramiensch bad» (Sieburgh in 1842 , ibid.). Hoepermans in 1865 is vrij uitvoerig over deze "badplaats» aan de "kali Sindjoijo" (Rapporten Oudheidk. Dienst N. I. 1913, p. 208-209). Deze kali Sěndjåjå 
is natuurlijk een rivier die in haar naam onmiddellijk teruggaat op den ouden Keḍoe-Mataram-Vorst Sa ndjaja. En vlak daarbij, even Noord, ligt de desa Tingkir (men vergelijke Verbeek's Kaart; Blad III); d. i. de historisch-vermaarde desa van Ki Djåkå Tingkir, "den Jongeling van Tingkir", alias Mas Karebet, .... den Eersten Sultan van Padjang ( $\pm 1568-1582$; verg. o. a. Veth's Java, $2^{\text {en }}$ druk, I, 1896 , p. $267-268$ en $300-301$ ), den zoon van den vermoorden Regent van Pengging. Welk Pěngging weer een nu nog vermaarde groote bronvijver is in 't Kartasoera'sche, W. ten Z. van de suikerfabriek Bangak, met eenige overblijfselen van Hindoe-beelden. '

Men behoeft slechts een heel klein beetje inzicht te hebben in de Javaansche geschiedenis en het Javaansche gemoed, om te begrijpen: dat de eerzuchtige zoon van een vermoorden Regent uit het Padjang'sche zijn opgevoed-worden te Tingkir, aan den linkeroever der rivier genoemd naar Vorst Sandjaja-Zaliger, opvatte als een vingerwijzing van Allah naar zijn heerscher-worden later over èn Padjang èn Mataram èn Kẹdoe.

Waar Vorst Sandjaja van Kẹ̣oe-Mataram in zijn Tjanggalinscriptie van 654 Çaka bleek te zijn een warm Ciwaïet, mag ondersteld dat die mythische "Sandjaja in Voor-Indië, naar wien hij zich blijkbaar noemde, evenzeer Ciwaïet was. Want dat die "Gelukzalige Sandjaja» in Voor-Indië - hoogstwaarschijnlijk zelfs in Zuidelijk Voor-Indië, Zuidelijk-Dekhan - te zoeken is, staat van te voren wel vast; aangezien in de eigen strophe 7 van die inscriptie, nà het vermelden van het "voortreffelijk, onvergelijkelijk eiland, Java genaamd, een "allerheerlijkst miraculeus heiligdom van Ciwa» wordt vermeld - toch wel gewis op den Diëng te denken! --, dat was overgebracht van den in 't gezegende land $\mathrm{Ku}$ ñ jarakuñ $\mathrm{a}$ de ça gevestigden "stam», gelijk men het noemt. Met welk Kuñjarakuñja of kortweg Kuñjara (zooals Prof. KERN bij deze vertaling in 1885 opmerkte; Bijdr. Kon. Inst. 4, X, p. 130, of herdruk Verspr. Geschr. VII, 1917, p. 122) «eene streek in Zuidelijk Indië, wel

1 De laatste uitgave der Residentie-kaart van Soerakarta, Herziening 1894, uitgave 1907, heeft (beN.O. de enclave Ampel) foutief: "K. Pendjojo"; en (beW. Kartasoeraj voor Pěngging zoowaar: "Peni"! De kali Sěndjåjå vereenigt zich bij de halte Tĕmpoeran met de kali Toentang tot de kali Dĕmak. Den bronvijver Pĕngging bezocht ik in Jan. 1890; hij ligt bij de historische desa Logĕnder (zie Brandes' Register op de Babad Tanah Djawi, 1900). 
bedoeld moet zijn, swaar een berg was door Ciwa geschapen .... en het verblijf van den Ziener Agastya»; d. w. z. van den Apostel der Tamil's!

Cliwaïtisch ook was de "Goden-berg», de Dihyang of Diëng, de centrale godsdienst-«Sinaï» van het oudste Midden-Java. Vandaar ook weer, dat dit laatste weleer zóó overwegend Çiwaitisch is geweest, daarnaast deels (en later) Boeddhistisch; maar niet Wishnoeïtisch, zooals toch de Hindoe-kolonie op West-Java tusschen ca. 400 en 500 A. D. was geweest, gedocumenteerd door den befaamden Vorst Poernawarman uit het Buitenzorgsch-Bataviasche. Doch Vorst Daksha, beheerscher van MiddenJava plus Oost-Java, was drie kwart Ciwaïet, en één kwart Boeddhist; hij eert het verleden zóózeer, dat hij tot hulde aan den mythischen stamvader Sandjaja (in het land Koendjara, alias Koendjarakoendja; dat met den laatsten naam door zijn Javaanschen voorzaat, Koning Sandjaja, in 654 Caka uitdrukkelijk als stamland is vermeld) eene nieuwe Aera instelt; maar hij is tevens in zooverre een "moderne» Hindoejavaan, dat hij binnen de hóógstens 10 jaar van zijn Vorst-zijn (of misschien maar 5) in de onmiddellijke buurt van Prambanan onder aanroeping van Ciwa en Doerga een Boeddhistisch klooster begiftigt, en het jaar daarna door zijn Grootvizier en een Rijksgroote, alweer in de naaste buurt van Prambanan, ter eere van zijn Javaanschen voorzaat, Koning Sandjaja, een vrijgebied laat stichten - waarover hij immers, als Vorst, alleen te gezeggen had! -, ditmaal onder aanroeping van Ciwa èn Boeddha, en met invlechting in den uitvoerigen tekst van 3 maal den naam van den heiligen Ciwaitischen berg van Midden-Java, den Diëng.

$\mathrm{Nu}$ rijst voor ieder die nadenkt, vanzelf een gewichtige vraag.

Te Prambanan verheft zich dat merkwaardig complex van den Tjaṇdi P(a)rambanan, met den tempel van Çiwa in 't midden als hoofdtempel, gericht naar het Oosten, met ten Noorden daarvan - d. w. z. ter slinkerhand (k i wå) - den Wishnoe-tempel,

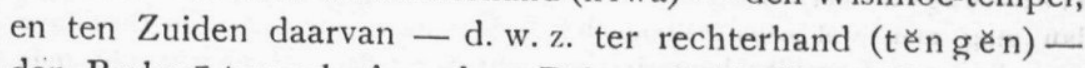
den Brahmā-tempel. Aan deze Drie-eenheid, Çiwa, Wishnoe, en Brahmā (in deze volgorde .' ${ }^{1}$, met Ciwa als Oppergod (Mahādewa)

1 Aan den Mĕndoet kan men door de plaatsing der 3 soorten van lotus-bloemen in de reliefs met de aanzwevende hemelingen vóór aan het voorportaal (n.l. één hemeling met een knop van den heiligsten Indischen lotus, den breedbloembladigen roserooden lotus, Nelumbium speciosum Willd., op het Dl. 74 
in 't midden, is een overvloed van relief-beeldhouwwerk gewijd, dat..... voor ca. 50 pCt. Boeddhistisch mag heeten in opvatting, in godsdienstige sereniteit van de hoofdfiguren; terwijl de andere $50 \mathrm{pCt}$. goeddeels zijn gewijd aan de Daden van den Geweldigen $\mathrm{R} \overline{\mathrm{a}} \mathrm{m}$ a, den Veroveraar van Zuid-Indië, den Achterkleinzoon.... van $\mathrm{R}$ a g hoe, welke laatste met name door Vorst Sandjaja van Kẹ̣oe-Mataram in 654 Caka wordt geëerd (strophe 11 der inscriptie van Tjanggal; zie p. 146 hiervóór) als Model-Vorst, immers-als eene "die.... het gebied van verscheidene naburige vorsten veroverd heeft .

De bouwperiode van den Tjandi Prambanan, dien drie kwart openlijk-Çiwaïtischen en één kwart verholen-Boeddhistischen tempel, wordt sinds bijna dertig jaren algemeen erkend als te rekenen te zijn kort vóor 850 Caka - toen Midden-Java ging zwijgen, en Oost-Java ontbloeide - ; de stijl er van geldt als merkwaardigsynkretistisch, en als een overgang van den klassieken Middenjavaanschen tot den zich verinlandschenden Oostjavaanschen stijl.

De slotsom ligt voor 't grijpen: moet niet met gróóte mate van waarschijnlijkheid Daksha, toen hij in ca. 820 Çaka Rijksbestierder werd van Midden- en Oost-Java, de Stichter zijn ge-

rechterportaal, dus in 't N. O.; doch twee hemelingen achter elkaar, met resp. een blauwen scherpbloembladigen lotus, Nymphaea stellata.Willd., en een witten scherpbloembladigen nacht-lotus, Nymphaea Lotus L., op het linkerportaal, dus in ' $t \mathrm{Z}$. W.) beslist constateeren: dat hier resp. niet alleen Brahmā, Wishnoe en Çiwa door de drie hen verzinnebeeldende lotusbloemen, hulde brengen aan den Boeddha; doch tevens: dat hier, naar goeden Hindoe-trant, rechts hooger is dan links, en de ééne rose lotus aan den dageraads-kant hóóger rekent dan de twéé Nymphaea's aan de avond-zijde. Desgelijks is ook in het sanctuarium. van den Mĕndoet, het Padmapāṇi-beeld (alias Awalokiteçwara), aan de rechterhand van den centralen Mensch-Boeddha gezeten, hóóger dan het Mandjoeçrī-beeld aan diens linkerhand; of, zooals het in R. K. kerktaal zou kunnen heeten: de Padmapāṇi in den Mĕndoet zit aan den Evangelie-kant, de Mandjoeçrī aan de Epistel-zijde.

Bij Prambanan mag men vragen, of dáár sıms al niet het echt-Javaansche kiwa-tĕngĕn doorbreekt, dat later Jav. hofzede is geworden? Zoo neen, dan mag men wel eens nagaan bij de jongere monumenten op Oost-Java waar daar een dergelijke kentering van opvatting dan wèl, en met voldoende waarschijnlijkheid, vermoed mag worden.

Dat bij al dit "rechts" of "links" steeds van het centrale Godenbeeld uitgegaan moet worden, spreekt van zelf; evenals in een R. K. kerk van het Christus-beeld in 't midden van het koor; bij Garĕbĕg's van den Vorst; in onze (Gothische) heraldiek van het blazoen-zelf. Over de 3 soorten van lotusbloemen bovengenoemd, verg. nader mijn stukje "Lotus" in den $2^{\text {den }}$ druk der Encyel. v. N. I., dl. II (1918). 
weest van den Tjanḍi Parambanan, die in ca. 840 Caka, toen hij reeds eenige jaren Vorst was over het geheele Rijksgebied, voltooid of zoo goed als voltooid was?

Waar we tot nog toe in absoluut duister tasten omtrent de stichters - deels stichtsters? - van den Boroboedoer of Menndoet, zouden we dan voor het complex van $\mathrm{Tj}$. Prambanan een begin van licht hebben.

\section{Een zeldzame hulde aan Rijksbestierder Gadja(h)mada, in 1265 en 1269 Caka.}

Het Mandjoeçri-beeld van 1265 Çaka $=1343$ A. D., tot schande van ons land sedert 1862 prijkend in het Museum van Volkenkunde te Berlijn ${ }^{1}$, vertoont op het heupkleed van den Heilige. een allermerkwaardigst kleedij-patroon. Prof. GRÜNWEDEL heeft dit voor de eerste uitgave van zijn Buddhistische Kunst in Indien (1893) op p. 56 laten reproduceeren naar, blijkbaar, eene penteekening; in den tweeden druk - alleen op den stempelband, niet op het titelblad, als zoodanig gekenmerkt - van dit voortreffelijke Berlijnsche handboek (1900), werd zij op de helft verkleind en veel minder sprekend op pag. 56 nogmaals opgenomen. Hiernaast werd zij als tekst-illustratie weergegeven naar

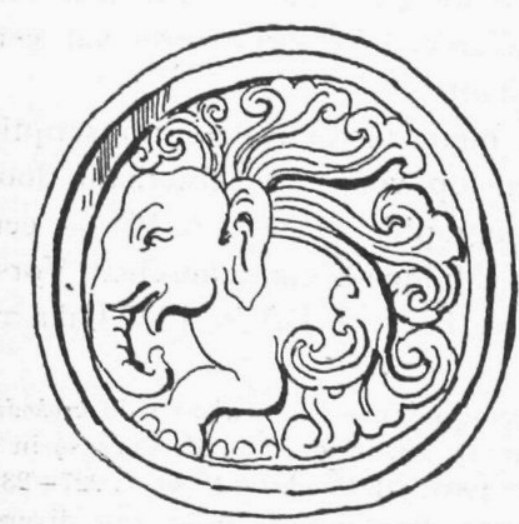

die eerste krachtige afbeelding van 1893 .

Beide malen plaatste er Grünwedel hetzelfde onderschrift bij: "Meerelefant: Makara, aus dem Gewandmuster des altjavanischen Mañdschuçrî̀.

$\mathrm{Nu}$ stuit men bij dit onderschrift al dadelijk op de tegenstrijdigheid met Grünwedel's eigen opvatting, ook elders in dit handboek (men zie het Register), dat de "Makara " de naar Indischen trant vervormde "Dolfijn» der Grieksche Aphrodite zou zijn («der Delphin der

1 Men zie hierover mijn uiteenzetting in de Singasari-Monographie (1909), p. 115-116. Men verbetere daar op r. 17 v. o. de drukfout „onder" in "oder". 
Aphrodite gab die Vorlage», 1. c.), waaruit dan ontstond: "Der Meerelefant Makara, ein Wesen, zusammengesetzt aus dem Vorderleib eines Elefanten mit dem Unterleib und Schwanz eines Fisches». Dit schrijft hij op dezelfde bladzijde, waar hij bovenstaande afbeelding geeft. Wáár echter heeft het Hindoesche makara-motief ooit twee zware olifants-pooten te zien gegeven, zooals hier?

Dit wordt, met permissie, stelselzucht; het is geen kritisch bekijken meer van wat men voor zich heeft.

De ommestaande afbeelding spreekt voor zich zelf. Dat het makara-motief er ten deele mee wordt uitgedrukt - dat is dus de vervormde dolfijn, waaraan de Indiërs den olifantskop en de olifantsslurf gaven ${ }^{1}$; misschien ook onder den indruk der waterzuilen die verscheiden walvisch-achtigen opspuiten - is onmiskenbaar; bovendien komt dat motief, naar de opmerking van VAN ERP in 1909, voor aan den Měndoet bij den Mandjoeçrī, ${ }^{2}$ aan de linkerhand van het naakte Boeddha-beeld gezeten. Maar méér, véél meer nog, is in dit Oudjavaansche kleedij-motief een wezenlijke olifant teruggegeven, met twee krachtige voorpooten, een nederwaarts - en niet in makara-trant opwaarts - gekrulde slurf, met nauwelijks -iets wat op een staart lijkt - die in de heusche makara-afbeeldingen altijd zoo uitvoerig behandeld wordt - , doch met zwierende gebundelde krullen boven den rug, welke aan het geheel alleréérst het type geven van een (sit venia verbo!) "vliegenden olifant".

$\mathrm{Nu}$ is dit Mandjoeçri-beeld - men zie de laatste transcriptie met vertaling van de inschriften op voor- en achterkant door Prof. KERN in de Singasari-Monographie (1909), p. 101 - een schenking (oprichting) van den Midden-Sumatraanschen Vorst Adityawarman (vóór 1343--nà 1375 A. D.) in 1265 Caka =

1 Volgens anderen echter is het prototype van de makara de krokodil. Prof. Voges maakt mij daarbij attent op het opstel van H. Cousess in 't Annual Report Arch. Survey of India, 1903-04 (Calcutta, 1906), p. 227-231, "The makara in Hindu ornament", met vergelijkende plaat van diverse makara's, oude en jongere; waarbij ook enkele af beeldingen zijn die aan een rhinoceros doen denken. De eind-indruk is, dat men niets zekers kan zeggen, evenmin als omtrent den waren oorsprong van de Chineesche draak-figuur of de Gothische spuier-gedrochten. Natuur-indrukken van meer dan één vervaarlijk gedierte werden hierbij verwerkt door een goede dosis fantasie van versuhillende kunstenaars.

3 Zie Twentieth Century Impressions of Netherlands India (1909), p. 148. 
1343 A. D.; ter eere (op den voorkant) van deze Boeddhistische Godheid, en onder uitvoerige vermelding (op den achterkant), na kortelijk zijn eigen naam, van «Hare Majesteit de Opperkoningin " uit wier "geslacht» hijzelf afstamde. Met deze "Opperkoningin» wordt echter niet bedoeld de toen regeerende KoninginRegentes van Java, Djajawishnoewarddhanī (1329 - 1350 A. D,), moeder van Hajam Woeroek, zooals t.a.p. nog aangenomen werd; maar dier eigen toen nog levende moeder, de KoninginDouarière (Rādjapatni; de Ratoe Ageng, zou men thans in de Vorstenlanden zeggen), zooals Dr. KROM in 1916 heeft bepleit ' ${ }^{1}$, en waarmee Prof. Kern zich toen vereenigd heeft.

Doch daarnààst regeerde als Rijksbestierder van Madjapahit sinds 1253 Caka $=1331$ A. D. - niet pas sedert 1268 C.. ${ }^{2}-$ de befaamde Gadjah Mada (in Sanskrit-vorm Gajamada; in 't Mal. Gadjah m ěta), d. w. z. de "Geile (= Woest-sterke, Wilde) Olifant ", die in 1272 Claka $=1350$ A. D. de Bismarck zou worden van den toen optredenden jongen Vorst $\mathrm{Ha} \mathrm{ja} \mathrm{m} \mathrm{Woe} \mathrm{roek,}$ het "Hane-Jong".

Men begint al te voelen, welk keurig hovelings-compliment de Sumatraansche Vorst Adityawarman in 1343 A. D. "op Javaanschen bodem, (zooals de achterkant van het Mandjoeçrīinschrift zegt), na den lof aan "Hare Majesteit de KoninginDouarière, heeft willen brengen aan Rijksbestierder Gadjah Mada in bovenstaand opmerkelijk en symbolisch kleedij-patroon.

Maar vier jaar later, in 1269 Caka $=1347$ A. D., laat dezelfde Vorst Adityawarman, ditmaal op Sumatraanschen bodem, immers te Padang Tjandi, in het landschap Dharmāçraya $=$ Sigoentoer ${ }^{3}$, aan den bovenloop der Batang Hari, een Amoghapāça-beeld wijden door zijnen Patih; en in het uitvoerig Sansktit-opschrift op den achterkant van dit beeld - men zie het opstel van Prof. KERN in Tijdschr. Bat. Gen. XLIX, 1907, p. 159-170; of den herdruk in diens Verspr. Geschr. VII, 1917, p. 163-175-, wordt, in een soort Indonesisch Sanskrit dat Prof. Kern "galimathias » noemt, in den aanvang Adityawarman-zelve verheerlijkt als "in edelaardigheid gelijkende op den olifant der woudspelonken

1 Verslagen en Meded. Kon. Ak. v. W., afd. Letterk., 5, II (1916), p. 335-336.

2 Zie Dr. Krom in Tijdschr. Bat. Gen. LVI (1914), p. 252-256.

s Zie mijn stukje in Notulen Bat. Gen. 1909, p. 117-118; en Dr. Krom in Versl. en Meded. (als boven, 1916), p. 326-329. 
(d.i. den wilden olifant) wegens s a n d o h a (= bronst-sap) en stem * (1. c. p. 163, of p. 169). D.w.z.: Adityawarman vergelijkt zichzelven met welgevallen in 1347 A. D., ditmaal in geschrifte, met den "Wilden Olifant", d. i.... met Gadjah Mada, die natuurlijk de fautor, de beschermheer, was geweest en gebleven van den Sumatraanschen Vorst aan het Koningshof van Groot-Java!

Een zeldzamer fijn-Oostersch compliment dan dat kleedij-patroon op het 4 jaar oudere beeld van den Mandjoeçrī - die ook in de $3^{\text {e }}$ strophe van het Amoghapāça-beeld nog met name gehuldigd wordt; zie Kern, 1. c. p. 164 of p. $170-$, zal echter wel niet in de heele Hindoejavaansche ikonographie te vinden zijn! 